\title{
The Legal Protection of Competition in France ${ }^{\dagger}$
}

\author{
Stefan A. Riesenfeld*
}

I

INTRODUCTION

7 HE ESTABlishment of the European Coal and Steel Community under 1 the Treaty of Paris of April 18, 1951 and of the European Economic Community under the Treaty of Rome of March 25, 1957 has gone a long way in fusing the economies of their member nations, that is France, Germany, Italy and the three Benelux countries into a single large scale unit. The creation of the common markets, first for coal and steel products ${ }^{1}$ and subsequently for the other products, ${ }^{2}$ has been an important factor in the startling economic recovery and advance of the six countries, the combined population of which closely approaches that of the United States. ${ }^{3}$ The new marketing opportumities flowing from the impressive increase in purchasing power in the community nations and the concomitant improvement in the standard of living of their people, coupled with the need for operating inside the customs wall surrounding the Inner Six rather than relying on

† This article is a slightly expanded chapter of a forthcoming study entitled the Protection of Competition in the European Common Market by the same author. The whole paper will appear in a two-volume collection of contributions by several authors dealing with various aspects of the European Economic Community, entitled The European Economic Community -A Legal Profile and published under the editorship of Professor Eric Stein of the University of Michigan School of Law. For convenience of the reader a translation of the most important French statutory provisions against anticompetitive practices is added in the Appendix.

* Emanuel S. Heller Professor of Law, University of California School of Law, Berkeley.

1 The evolution and activities of the European Coal and Steel Community, operating since August 10, 1952, nay best be gleaned from the eight annual General Reports on the Activities of the Community (1953-1960), submitted by the Higb Authority to the Common Assembly or, its successor, the European Parliament. See also Drebord, The Schuscan Plan A Study in Economac COOPERATION, 1950-1959 (1959).

2 For information on the progress and operations of the European Economic Community, active since Janary 1, 1958, see especially the three annual General Reports on the Activities of the Community (1958-1960), submitted by the Commission of the EEC to the European Parliament. Both communities, of course, publish a great deal of additional statistical and other data.

3 The population of the six commumity countries at the end of 1957 totalled 165.153 million inhabitants, EEC COMOM'N, REPORT ON THE ECONOMIC SITUATION IN THE CoUNTRIES OF THE Community 61 (Table 4) (1958). 
imports, have attracted American and other foreign participation in the intracommunity production and distribution at an ever increasing rate. ${ }^{4}$ As a result the juridical framework for business operations inside the European Common Market has become of considerable importance to the legal profession in other countries.

It was the intention and the goal of the architects of these new communities to rely on competition as the principal auto-mechanism of their common markets and as a main force making for technological progress and economic growth. For that reason provision for the legal protection of competition against restrictive practices by enterprises and other distortions were inserted as essential portions in the treaties of Paris and Rome. ${ }^{5}$ Because of the variety of political and legal considerations these measures could be no more than the keystones in the composite legal structure that forms the bulwark against impairment of the competitive market order and had to be implemented and supplemented by the national laws dealing with the subject as enacted by the individual states. Accordingly, since 1952 the governments of the six commurity countries have been greatly concerned with the introduction of an adequate legal framework and machinery for the control of anticompetitive practices and France, as well as Germany, ${ }^{6}$ the Netherlands ${ }^{7}$ and Belgium ${ }^{8}$ have passed important recent legislation against cartels and other restrictive practices.

The following study is designed to present a picture of the development and present status of the legal protection of competition in France. ${ }^{3}$

4 This development which actually has produced some anxiety in the community countries, was presaged in American banking circles, see Chase MaNHattan Bank, THE NEW EURopean MARRET-What IT MEANS To U.S. BusINESS 37 (1958). Investments in form of plant and equipment expenditures of U.S. companies in the Common Market countries rose to $\$ 361,000,000$ in 1958, an increase of $\$ 62,000,000$ over the preceding year, U.S. Dept of Cominerce, Indistry Expands Investment Abroad, Survey of Current Business, Oct. 1959, p. 16, 20.

5 See especially ECSC-Treaty, arts. 65-69 and EEC-Treaty, arts. 85-90. For discussions of these articles see O'Brien, The "Antitrust" Provisions of the European Common Market Treaty, in 16 A.B.A. AntrTRUst Section 118 (1960); Lang, Trade Regulations in the Treaty Establishing the European Coal and Steel Community, 52 Nw. U.L. REv. 761 (1958).

${ }^{6}$ Law Against Restraints of Competition of July 27, 1957. [1957] BGBl. I 1081. An English translation of the law was published by the U.S. DEPT. OF COMNMERCE, WORLD TRADE INNFORMTATION SERVICE, pt. I, No. 58-1 (1958).

7 Economic Competition Act of 1956/1958. [1956] Stb. No. 401; [1958] Stb. No. 412-13. An English translation of the law can be found in 2 European Productivity Agency of the Organization for European Economic Cooperation, Gume to Legisiation on Restrictive Business Practices in Europe and North Amertca (1960).

8 Law Against the Abuse of Economic Power of May 27, 1960. Moniteur Belge, June 22, 1960.

${ }^{9}$ For a brief discussion of the same subject see Goldstein, Effect of Foreign Antitrust Laws on United States Business, 12 Sw. L.J. 405, 420 (1958). 


\title{
II
}

\author{
HISTORICAL EVOLUTION
}

\section{A. Period Prior to 1945}

\section{Development}

French law governing restrictive business practices is the product of rather late growth. ${ }^{10}$ During the nineteenth and the first part of the twentieth century there existed only limited concern about the curbing of such activities and, at some periods between the two world wars, concentration and cartelization were even fostered officially, especially by administrative action. As a result the French approach to the protection of competitors, whether viewed from a factual or legal aspect, is quite complex and rather difficult to describe. For reasons which will become apparent, the evolution of French law can be divided into three nuajor periods.

The traditional liberalistic tendencies of French decisional law and legal doctrine until comparatively recently made the courts quite hesitant to interfere with business practices. A statute of March 2-17, 1791 had liquidated the medieval restrictions on the access to professional and commercial life and proclaimed freedom of trade. ${ }^{11}$ The Code Napoléon a little later elevated freedom of contract to a cardinal principle of the French legal system. ${ }^{12}$ Where these two hiberties clashed, the courts were perplexed and floundering.

The chief statutory basis for resolving the dilemma was to be found in Article 419 of the Penal Code of 1810 , creating the crime commonly

10 French literature on the law governing cartels and other restrictive business practices Las become rather voluminous. Of the copious publications of comparatively recent vintage we mention Reuter, A propos des ententes industrielles et commercíales, 15 DroIx Sociar, 442, 508 (1952); 16 ibid. 1; Mazard, Prix imposés et prix d'entente, 16 Drorx Sociar 129 (1953); Souleau, La réglementation des ententes professionnelles dans le décret-loi dus 9 aouzt 1953, 16 Drorr Soctal 577 (1953); Moreau et Mérigot, Les ententes professionnelles devant la loi, in La Documantation Françarse, Ententes et Monopoles dans le: Monde, France No. 1736, May 5, 1953 (1953); Barbry and Plaisant, Libre concurrence et ententes industrielles, [1954] Dalloz [hereinafter cited as D.] I, 67; Souleau, Prix, in ENcxcopíone Daxloz, Répertoire de Droit Criminel 675 (1954); Soulcau, Spéculation Illicite, in EncyclopébI: DarLoz, Répertoire de Droit Criminel 865 (1954); Plaisant and Lassier, Les Ententes Industrielles sous.forme de Sociétés ou d'Associations, JoRIs-CrasseUR DEs Socifitss 178 (1955); Lassier, La réglementation de la concurrence et des ententes économiques en France: Bilan des trois premieres années d'application, Ligue Internationale contre Ia concurrence Déroyale, Communication No. 43, 14 (1957); Lassier, Monopoles et Pratique Commerciales Restrictives, International Bar Association Conference, Seventh Conference Report, 278, 1958; Castel, France, in Frurdmarrs, Antr-Trust Laws, A Cosmparative Srarpostum 91 (1956); Castel, Recent trends in compulsory licensing in case of non-use of patents: A comparative analysis, $36 \mathrm{~J}$. PAT. OFr. Soc'x 330 No. 5 (1954).

11 For the text see [1789-1830] Sirey, Lois Ann. 92.

12 CODE CIVII art. 1134. 
designated as distortion of the price level (altération des prix). Otherwise some isolated provisions and general principles developed by the courts had to serve the purpose.

Until its revision in 1926, Article 419 of the Penal Code proscribed and penalized: "the raising or depressing of the price level for victuals, merchandise or public securities above or below that which would have flown from natural and untrammeled competition" through two major types of conduct: either (a) "intentional dissemination in the public of false or calummious facts, the making of offers topping the price asked for by the sellers themselves, or any sort of fraudulent ways or means," or (b) "by combination or coalition among the principal holders of the same type of merchandise or victual, aiming at not selling it or not selling it except at a specified price." In applying this section, especially in respect to combinations, the courts vacillated from period to period, reflecting the changing moods of time. ${ }^{13}$ At first the courts favored a broad construction. Thus the statutory terms "victuals" and "merchandise" were held to include transportation, ${ }^{14}$ and the actual raising or lowering of the price level was not considered critical if the purpose of the combination was the attainment of such results. ${ }^{15}$ The passage of the Law of 1884, establishing full freedom of association ${ }^{16}$ was deemed to be a legislative recognition of the principle that trade associations and combinations for economic purposes were not illegal per se and resulted in, or at least strengthened, a doctrinal and decisional trend of differentiating between "good" and "bad" cartels." Combinations of manufacturers were found not to be illicit even where they engaged in price-fixing, division of markets, or restriction of produc-

13 For a detailed analysis see Moreau in Moreau et Mérigot, op. cit. supra note 10, at 38.

14 The two leading cases in that respect involved a combination of two stagecoach companies which attempted to undersell their competitors, Messageries Royales et Générales c. Guérin, Cass. Crim. Div. 1836, [1836] Sirey, Jur. 882 ; Messageries Françaises c. Messageries Royales et Générales, Cass. Crim. Div. 1839, [1839] Sirey, Jur. 722.

15 As early as 1850 the Supreme Court of France declared in a case involving an agreement between local merchants and ship captains stipulating for discriminatory freight charges against outsiders "that in a commercial matter it is not necessary that the decision which finds the perpetration of a coalition declare expressly that the result of the combination was a raising or lowering of the price level of goods so long as the whole of the decision is to that effect." Gombaud c. Petit, [1850]. D. I, 212.

16 [1884] D. IV, 129. Arts. 2 \& 3 thereof provided: "The trade unions or associations, even of more than twenty persons exercising the same profession, similar trades or connected professions concurring in the manufacture of specified products, may be established freely without governmental authorization." "The trade unions have as their exclusive object the study and the protection of economic, industrial, commercial and agricultural interests."

17 Illustrative of and analyzing this trend are especially the long annotation by Professor Percerou to a decision of May 3, 1911 by the French Supreme Court in Gaillard et autres c. La Renaissance, [1912] D. I, 33, 39, and the opinion by Justice Michel-Jaffard in the same case, $i d$. at 40 . This case involved a combination of plate glass cutters and polishers providing for cooperation in production and standardization of pricing practices. 
tion, ${ }^{18}$ and the French Supreme Court went along in sanctioning such holdings. ${ }^{19}$ As a consequence the provisions of Article 419 of the Penal Code appeared more and more to be anachronistic and a revision of the law relative to status of combinations was felt to be in order. In 1926 an amendment became reality, ${ }^{20}$ and the pertinent section was overhauled. In its new and current form article 419 penalized the effectuation of, or the attempt to effectuate, an artificial rise or fall of the price level for victuals, merchandise or public or private securities (a) by specified or other fraudulent maneuvers or (b) by individual or concerted action on the market with the purpose of obtaining a profit which would not result from the natural play of demand and supply.1 Actually, the new law, apart from closing certain gaps relative to attempts and individual action, engendered little change. Combinations were held illegal only in infrequent and comparatively minor cases of local character which, as Professor Reuter has so aptly put it, smacked of a setting borrowed from a Balzac novel. ${ }^{22}$

Where a combination is illicit because it aims at or results in excessive profits or the elimination of competitors the participants are not only subject to criminal prosecution but may be held liable for damages by the injured competitor. ${ }^{23}$ Moreover, dissatisfied parties may have the agreement annulled by civil action ${ }^{24}$ or assert its invalidity as a defense if the other members of the combination attempt to collect stipulated damages for breach thereof. ${ }^{25}$

The economic crisis of the thirties and the impact of World War II resulted in a further strengthening of the status and role of the cartels.

18 See, for instance, the decision of the Appellate Court of Nancy of 1902 in the matter of the Comptoir Métallurgique de Longwy, involving a combination of the principal foundries in Lorraine providing for common purchases, production quotas, fixed sales prices, etc., discussed by Moreau in Moreau, et Mérigot, op. cit. supra note 10, at 41, and by Plaisant and Lassier, op. cit. suspra note 10 , at 9 and 13.

19 E.g., in the case of Gaillard et autres c. La Renaissance, supra note 17.

20 For the legislative history see Moreau in Moreau et Mérigot, op. cit. suspra note 10, at 42.

21 "Anyone (1) who by means of false or calummious facts disseminated intentionally in the public, or by offers thrown on the market with the purpose of disturbing the quotations, or by offers topping the prices deinanded by the sellers themselves or by whatever other fraudulent ways and ineans; or (2) who by perpetrating or attempting to perpetrate an action on the market, whether imdividually or in concert or coalition and with the purpose of securing a profit not resulting from the natural play of supply and demand, directly or through a middleman. effectuates, or attempts to effectuate, an artificial rise or fall of the price for victuals, wares, or public or private securities, shall be punished with imprisonment . . . or a fine. ..."

22 Reuter, $A$ propos des ententes industrielles et commerciales, 16 Droit Social 1, 4 (1953).

23 See, e.g., Messageries Royales et Générales c. Guérin, supra note 164, holding that art. 419 permits the institution of a prosecution by the injured competitor coupled with the recovery of damages.

24 See, e.g., Gombaud c. Petit, suspra note 15.

25 See, e.g., Gaillard et autres c. La Renaissance, supra note 17. 
In France, as in most other countries, there was a widespread belief that the great depression was caused by overproduction and consequent disorganization of the market and that the cure was to be found in a strict self-regulation by the various branches of industry and commerce. As a result, the government between 1935 and 1938 proceeded to foster or even require cartelization in a number of industries and trades and obtained power to do so in a number of other instances. ${ }^{26}$ The sugar industry, ${ }^{27}$ shoe manufacturing, ${ }^{28}$ high sea fisheries, ${ }^{29}$ the potassium industry, ${ }^{30}$ and the export trade $\mathrm{e}^{31}$ are perhaps the most important instances of such action.

\section{World War II}

World War II brought about a complete transition to a controlled economy in the form of the authoritarian corporative state, ${ }^{32}$ which was formally terminated by a statute of $1946 .^{33}$ Yet, there still survived numerous semi-official trade associations which had been formed during the crises and wartimes and which appeared to be ripe for liquidation. This was accomplished by a decree of 1949 and a regulation of 1950 implenenting it. $^{34}$ However, this action failed to make a clean sweep. The government retained certain compulsory combinations and subcombinations with official functions, especially in the steel industry and the coal import trade, and,

26 For a detailed discussion of this phase of French legislation see Moreau in Moreau et Mérigot, op. cit. suspra note 10 , at 63-75.

27 Decrees of Aug. 8, 1935 and Oct. 30, 1935, [1935] D. IV, 252, 533.

$28 \mathrm{Law}$ of Mar. 22, 1936, inplemented by regulation of Mar. 26, 1936, [1936] D. IV, 155, 160 and Law of Apr. 7, 1936, [1936] D. IV, 160.

29 Decree and regulation of Jan. 14, 1936, discussed by Moreau in Moreau et Mérigot,

${ }^{30}$ Law of Jan. 23, 1937, [1938] D. IV, 156.

31 Decree of May 24, 1938, [1938] D. IV, 259, discussed by Teitgen, in Note, I DrorT SOCTAL 237 (1938).

32 The two main legislative enactments establishing the framework for this action were the law of July 11, 1938 regarding the organization of the nation in time of war, [1939] D. IV, 209 (especially arts. 46 and 49), and the Law of Aug. 16, 1940, regarding the provisional organization of industrial production, [1940] D. IV, 253. See Noyelle, L'économie dirigée selon la loi • du 16 aoŭt 1940, 7 Coliecron Drorr SOCtAI 4 (1941); Teitgen, L'organisation provisoire de las production industrielle et les principes du droit prublic français, 9 Colsectron Drorr Social 2 (1941); Personnaz, Les Grousements d'importation et de répartition, 18 Collection Drorr SOCLAL 23 (1943).

33 Law No. 46-827 of Apr. 26, 1946, effectuating dissolution of the professional organisms, [1946] D. IV, 195.

34 Decree No. 49-1236, modifying the conditions of liquidation of certain organisms of the para-administrative sector, JouRNaI OFFICIEL DE IA RÉpubIIQUe FraAçaISE [liereinafter cited as J.0.] Sept. 12, 1949, 9278 (1949); regulation of Jan. 11, 1950 of the Minister for Finances and Economic Affairs, specifying the organisms affected by the decree 49-1236, J.0. Jan. 11, 1950, 395 (1950). 
as a consequence, found itself involved eventually in a protracted controversy with the High Authority of the European Coal and Steel Community. ${ }^{85}$

\section{B. The Period From 1945-1952}

The recoil from the system of the corporative state launched by the Vichy government brought a return to the free market economy. Neverthe-

35 For details see European Coal and Steel Community, High Authority, Fourte GenERar Report, 147 (1956); Fifth Generat Report, 130, 157 (1957); Sixtr Generai Report II, 93 (1958); Eighth General Report, 195 (1960). The facts, as gathered from these reports and inquiries by the author, are as follows: In November 1944 the shortage of both coal and foreign currency prompted the organization of a private non-profit corporation, styled A.T.I.C. (Association techmique de l'importation charbonnière), which included as members the major importer-consumers and representatives of the professionally recognized inporter-distributor, the latter being organized in two trade associations called, respectively, G.P.I.R. (Groupement professionnel des importeurs revendeurs) and G.P.I.R.T. (Groupement professionnel des importeurs revendeurs par voie terrestre). Subsequently, in 1944 and early in 1945, the Ministry of Industrial Production charged A.T.I.C. with certain public functions. Its activities were placed under the supervision of a government commissioner and the State was entitled to nominate the president of the corporation. The nationalization of the French coal mines by the Law of May 17, 1946 ([1946] D. IV, 230) entailed a further strengthening of the prerogatives and functions of A.T.I.C. Meanwhile the government also had undertaken a re-definition of the functions of the various cartel-agencies of the steel industry by regulation of June 28, 1947 (J.0. 6234). A corporation called C.P.S. (Comptoir français des produits sidérurgiques) was recognized as the joint sales agency of the steel industry, in charge of the allocation of orders, as well as the delivery terms. Another corporation called O.R.C.I.S. (Office of réparation des coinbustibles pour l'industrie sidérurgique) was placed in charge of the coal industry's procurement, having a monopoly with respect to all plants using at least 100 tons per month. A.T.I.C. henceforth was composed of the two importer-distributor organizations mentioned above, and a few of the largest consumers, such as O.R.C.I.S., the Eléctricité de France and the Société Nationale des Chemins de Fer. By Decree No. 57-46 of January 24, 1948 (J.0. 791) it was established that both the purchase and transport, until dehivery to its destination, of foreign coal could not be effectuated except through an association of importers, the reciprocal obligation to be regutated by agreement between the governinent and the association; and in consequence of this provision A.T.I.C. on April 7, 1948 was placed in charge of these functions. In 1952 in order to conform with the French law of 1952 regarding price-fixing in anticipation of the impending establishment of the European common market for steel, the steel industry changed the status of the C.P.S. into a trade association, with mainly statistical functions. The structure and functions of A.T.I.C. and its components, however, remained unchanged. As a result the High Authority felt that this setup in the French coal industry was inconsistent with the Treaty and entered into protracted negotiations with the French government. The French government was willing to, and did, deprive O.R.C.I.S. of its legal coal purchase inonopoly for the steel industry and opened inemberslip in G.T.I.R. and G.P.I.R.T. to all authorized importers. Moreover, by Decree No. 57-46 of January 14, 1957 (Dall. Bull. Lég. 72) it changed the position of A.T.I.C. witl respect to coal purchases in the countries belonging to the European Coal and Steel Community to that of a broker or agent, free from administrative veto or instruction. As this action still required French buyers to procure non-French Community coal through the state-controlled cartel agency and to purchase from non-French dealers in the Community through the medium of authorized Frencb dealers, the High Authority, on December 18, 1957, issued a decision finding that such regulation was incompatible with the duties under the Treaty. The French Government asked for review and annulment of this decision by complaint filed on February 26, 1958 (7 Journ. Off. de la Cominunauté Européenne du Charbon et de l'Acier 151 (1958). The written proceedings were completed at the beginning of 1959. Prior to oral argument the parties, by mutual consent, requested a continuance for the purpose of resuming negotiations for an amicable settlement. These negotiations are still in progress. 
less, this change-over was slow, beset with difficulties, and by no means complete. Certain sectors of the French economy, especially in the fields of banking, insurance, production and distribution of electricity and gas, and coal mining were withdrawn partially or totally froin private enterprise by means of the famous nationalization decrees of 1945 and $1946 .^{36}$ In the remaining areas retention of price control remained unavoidable at first. The war, of course, had necessitated in France, as elsewhere, the introduction of rationing and price controls. The latter was acconiplished by a series of price freezing decrees which culminated in the codification of October 21, $1940 .{ }^{37}$ The restoration of the Free French government was followed in 1945 by the enactment of a new comprehensive price control ordinance $^{38}$ which reproduced a great portion of the provisions of the prior legislation.

The Ordinance of June 1945, which since its passage has been the object of a steady stream of aniendments, defines and penalizes, in article 36 , a lengthy array of types of action labeled as "illicit pricing practices." This catalogue is followed, in the subsequent article, by the enumeration of additional categories of prohibited conduct, lumped together under the common designation of "offenses assimilated to illicit pricing practices." The latter list includes ${ }^{30}$ a variety of restrictive or discriminatory business practices. In the course of time it has been considerably expanded and has come to constitute the actual core of French legislation safeguarding economic competition. ${ }^{40}$

Article 37 of the Ordinance of June 1945, as originally enacted, proscribed three categories of restrictive business practices, committable by

36 See 1 Hamed and Logarde, Tratín de Droir Cosmorercial 37, 887 (1954) and the Laws of Dec. 2, 1945 (banking), April 25, 1946 (insurance), April 8, 1946 (gas and electricity) and May 17, 1946 (coal mining).

${ }^{37} \mathrm{Law}$ for the modification, completion and consolidation of price legislation, [1940] Sirey, Lois, Décrets etc. 1654.

38 Ordinance No. $45-1483$ of June 30, 1945, [1945] Sirey, Lois Ann. 1898.

38 Some of the infractions classified as "offenses assimilated to illicit pricing practices" cannot be considered as restrictive or discriminatory business practices, but merely as actions apt or calculated to thwart the inaintenance and enforcement of price controls. Thus art. 37 (1) (d) prohibits the failure to produce certain business records promptly upon request by the authorities. Conversely, some of the actions, proscribed under the rubric of illicit pricing practices may perhaps under certain circumstances assume a restrictive flavor, particularly the offense specified in art. 36(8) and styled as intervention of a new (i.e., noncustomary) middleman. For a discussion of the elements of this type of infraction see Souleau, Prix, EncycioPÉDIE DaLIoz, Répertoire de Droit Criminel 675 at 680 (1954).

10 As Professor Reuter has pointed out and illustrated so lucidly, the French price control system originally was conceived as an autonomous arrangement designed to determine ceiling prices. Yet quickly and to a steadily increasing extent it had to concern itself with the inechanics of the competitive process and to combat and proscribe certain restrictive practices while, on the other-hand, its administration on occasion necessitated resort to "dirigistic" and concentrative techniques, 16 DroIr SOCIAI I, 10 (1953). 
dealers, manufacturers or artisans: ${ }^{41}$ (a) the refusal to sell disposable stock-in-trade or to render feasible services; ${ }^{42}$ (b) arbitrary discrimination in the hours for the sale of different kinds of merchandise or for the rendition of different types of services; ${ }^{43}$ (c) tie-in clauses or quantity restrictions.4 In addition, the ordinance specified a general crime of speculative hoarding, committable either by persons other than merchants, artisans or growers with respect to any kind of commodity, or by merchants, artisans or growers with respect to commodities or goods foreign to their authorized trade or occupation. ${ }^{18}$

In $1946^{46}$ this list of offenses assimilated to illicit pricing practices was lengthened by inclusion of a prohibition against individual as well as concerted or collective action aiming at the thwarting of price control through threats or effectuation of withdrawal from activity as a dealer, manufacturer, or artisan. In 1947 further additions to and modifications of illicit pricing practices and offenses assimilated thereto were made. Thus, tying of an exchange of goods or services, outside of personal or family needs, to the sale of products, the rendition of services, or the offer of such sale or rendition was declared to be a further illicit pricing practice. ${ }^{47}$ Moreover, the definitions of the offense of speculative hoarding of inventory as committable by growers, manufacturers or merchants were clarified and expanded and the catalogue of article 37 was lengthened to conform to that change.

In 1952, at a time when the enactment of general cartel legislation was a much debated issue, the government decided to propose immediate and

11 Actually the three categories specified were incorporated from a prior decree of January 30, 1940, [1940] Sirey, Lois Ann. 1394.

42 Art. 37(1) (a): "To withhold products destined for sale by refusing to fill orders of purchasers within the himits of disposability or to refuse the filling of orclers for the rendition of services within the limits of available means, so long as such orders do not possess an abnormal character and the sale of these products or the rendition of these services are not prohibited by special regulation or subject to conditions which are not met."

$43 \mathrm{Art.} 37(1)$ (b): "Absent the applicability of any special regulation, to restrict the sale of certain products or the rendition of certain services to certain hours of the day, although the establishments or shops involved remain open for the sale of other products or the rendition of other services."

14 Art. 37(1) (c): "Absent the applicability of any special regulation, to condition the sale of any product or the rendition of any service upon either the simultaneous purchase of other products or the purchase of a required quantity or the rendition of another service." It may be mentioned in this connection that exclusive dealing contracts (as distinguished from tying clauses) were restricted in duration to a period of ten years by a statute of October 14, 1943, [1943] Sirey, Lois Ann. 1378, cf. Hémard, Les Contrats commerciurux, in Escarra et Radut, Tratré Théortque et Pratique de Droit Comarercial 66 (1953).

45 Ordin. of June 30,1945 , arts. $37(2)$ and 45 in conjunction with arts. 41-44.

46 Law No. 46-1024 of May 14, 1946, [1946] D. IV, 224.

47 Law No. 47-587 of April 4, 1947, art. I, [1947] D. IV, 148, aunending art. 36 of the Ordinance No. $45-1483$ of June 30, 1945. 
separate measures against concerted price-fixing. The result was the passage of law No. 52-835 of July 18, 1952 which added to the catalogue of offenses assimilated to illicit pricing practices in article 37 of the Ordinance of 1945 a new clause to that effect. It prohibited the imposition and maintenance of minimum prices by means of organized or collective action, except with respect to articles protected by a trademark or within the limits of governmental dispensation. The law provided specifically that it should cease to be operative upon the enactment of a general law on the subject of business combinations. ${ }^{48}$

In addition, the return of a relative abundance of goods necessitated the outlawing of a business practice which was deemed to permit large scale suppliers an undue advantage over their small competitors: the sale with gratuities. A statute of March 20, 1951 prohibited and penalized sales coupled with the distribution of gratuities of all sorts such as other merchandise, coupons, etc, ${ }^{49}$

\section{The Period Since 1953}

The year 1953 brought a special and more general regulation of the activities of combinations of enterprises. It constituted the climax of and, in a real sense, the anticlimax to, the long series of attempts during the preceding thirty years to obtain comprehensive parliamentary action determining the legal status of cartels and similar combinations. ${ }^{50}$ The sharp conflict between the two chambers about the scope and content of such legislation early in 1953 prompted the Laniel government to forego reliance on parliamentary action and to resolve the impasse by using the emergency powers in the economic field conferred upon the government by Law No. 53-611 of July 11,1953 for economic and financial rehabilitation. ${ }^{51}$ The result of this decision was the passage of Decree No. 53-704 of August 9,1953 relative to the maintenance or re-establishment of free competition in industry and commerce. ${ }^{52}$ Formally this Decree added a new sec-

48 Law No. 52-835 of July 18, 1952 [1952] D. IV, 259. For a detailed discussion of its history and significance see Mazard, Prix imposés et prix d'entente, 16 DroIt Soctal 129 (1953).

49 Cf. Hémard, Les ventes avec primes, 11 Revue Trar. DE Droit Commerciat 473

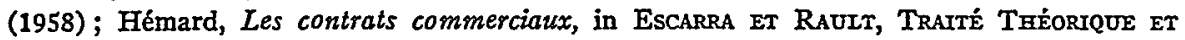
Pratique de Droit Comamerctal 63 (1953).

50 For a detailed discussion of the various French projects for a legislative determination of the status of monopolies and combinations of enterprises, see Moreau in Moreau et Mérigot, Les ententes professionnelles devant $l a$ loi, 93, 151 (La DocuMrentation Françatse, Recuems eT MonographIES, No. 21, 1953).

51 See Souleau, La réglementation des ententes professionnelles dans le décret-loi du 9 aoüt 1953, 16 Drort Soctal 577 (1953); Poinso-Chapuis, Le contrŏle des ententes professionnelles et le problème de la liberté des ententes, 16 Drorr Socrar 576 (1953); Barbry and Plaisant, Libre concurrence et ententes industrielles, [1954] D. I, 67 ; Delpech, Ententes Professionnelles, in I Dalloz, Répertoire de Droit Commiercial ET des Soclétés 783, 792 (1956). For the Law of July 11, 1953 see [1953] Dall. Bull. Lég. 511.

52 [1953] Dall. Bull. Lég. 587. 
tion entitled "Maintenance of free competition" to the Price Control Ordinance of 1945 (composed of articles 59 bis, ter and quater) and amended article 37 thereof which (as discussed above) defines and punishes offenses assimilated to illegal pricing practices.

The new article 59 bis prohibits, with qualifications subsequently specified, "all concerted actions, agreements, express or implied understandings, or combinations under whatever form or for whatever reasons, that have as objective or may have as result the restraint of the full exercise of competition by hindering the lowering of costs or sales prices or by facilitating an artificial rise of the prices."

Article 59 ter, however, exempts two categories of cases from this prohibition: (a) those in which the otherwise prohibited action was taken in compliance with a statute or regulation, and (b) those in which the actions could be justified as resulting in an improvement or extension of the markets for the production or as assuring the development of the economic process through rationalization and specialization.

Agreements and undertakings thus proscribed are declared void as a matter of private law, but the participants are barred from invoking the nullity against third parties. ${ }^{53}$ In addition, engaging, or inclucing to engage, in prohibited combinations was specifically included in the catalogue of offenses assimilated to illicit pricing practices. ${ }^{54}$

In order to assure the proper application and enforcement of the new régime, the Decree established a special administrative agency entitled Commission Technique des Ententes and composed of twelve members, of whom six were to be chosen from high-ranking judicial or administrative officers, four from business organizations, and two from the National Committee for Productivity. ${ }^{55}$ This body is given investigatory powers and charged with the responsibility of ascertaining whether or not violations of the terms of the ordinance have occurred and to initiate prosecution in case of such finding. Further implementation regarding the proceedings of and before the Commission was left to an administrative regulation which was issued on January 27, $1954 .{ }^{56}$ Moreover, by circular of March 31, $1954{ }^{57}$ the Ministry of Economic Affairs issued a detailed commentary explaining and construing the cartel provisions of the Decree of 1953. This

${ }^{53}$ Art. 59 bis. paras. 2 and 3.

54 Art. 37 (3), as revised.

55 Art. 59 quater.

56 Decree No. 54-97 of Jan. 27, 1954, [1954] D. IV, 86. For a discussion of the procedure of the Commission see Durand, La Commission Techrique des Ententes, 23 Drort Socrar 65 (1960).

57 Secrétariat d'Etat aux Affaires Economiques, Direction Générale des Prix et des Enquetes Economiques, Circulaire No. 65, entitled Instruction portant contmentaire des dispositions du décret no. 53-704 du 9 aoŭt 1953 relatives aux ertentes professionrelles. 
circular, though not possessing the force of law, has had decisive effect on the subsequent practice.

In addition to the new discipline of cartel activities the Decree of 1953 amended some of the already existing prohibitions of restrictive practices. Thus, the offense constituted by a refusal to deal was slightly rephrased and enlarged by a new interdiction of habitual discriminatory price increases not justified by cost differentials. ${ }^{58}$ Similarly, the scope of the prohibition against the maintenance of minimum prices was expanded in several respects and the exceptions clarified..$^{50}$ It should be noted, in particular, that now all vertical fixing of minimum prices, whether by an individual manufacturer employing the proscribed methods or by collective action, are condemned by the law. These two categories of infractions and their various elements formed the content of an elaborate administrative commentary, published by circular of February $15,1954 .^{60}$

In 1955, apart from a further addition (concerning formalities to be observed in sales on credit and installment sales) to the catalogue of offenses assimilated to illicit pricing practices, ${ }^{61}$ the government issued an important decree which again fostered and strengthened cartelization. ${ }^{62}$ By the terms of this enactment, government authorization could be obtained for the formation of enterprise combinations, with national or regional scope, for the purpose of plant rationalization or conversion. In addition, such combinations were enabled to obtain direct subsidies of various types,

58 The new definition of the offense (art. 37(1)(a)) reads as follows: "To refuse the filling of orders by purchasers of products or for the rendition of services within the limits of feasibility, so long as these orders do not present an abnormal character, emanate from good faith offerers and the sale of the products or the rendition of services are not prohibited by law or administrative regulation, as well as to engage habitually in discriminatory price increases which are not justified by cost differentials." For a detailed comparison between the new and the old elements of the offense, see Barbry and Plaisant, Libre concurrence et ententes industrielles, [1954] D. I, 67, 70.

58 The new definition of the offense (art. 37(4)) has the following form: "[It is unlawful] for any person to confer, inaintain or impose a minimum character upon the price of products and rendition of services or upon the commercial mark-ups, either by means of tariffs or price lists or by virtue of combinations, whatever may be their nature or form.

This subsection does not apply in cases where the products or services are the object of a dispensation granted by joint order of the Minister for Economic Affairs, the Minister of Commerce and the Minister having a particular interest in the matter. This dispensation, which in any event must be of limited duration, may be granted particularly in view of the novelty of the product or service; of the exclusiveness derived from a patent, a license of exploitation or the deposit of a utility model; of the need for a booklet of charges signifying warranty of quality and specification of condition; or of an advertising campaign for the purpose of launching.

60 For the complete text see [1954] D. IV, 96.

61 Decree No. 55-585 of May 20, 1955, [1955] Dall. Bull. Lég. 559.

62 Decree No. 55-877 of June 30, 1955, [1955] Dall. Bull. Lég. 740, implemented by Decree No. 55-1369, of October 18, 1955, [1955] Dall. Bull. Lég. 1012. 
and contributions to them by the member enterprises were declared to be tax deductible.

In 1958 the Council of State held that the Lamel government had lacked the powers for the imposition of penal sanctions for engaging in restrictive combinations. ${ }^{B 8}$ As a result the provisions of the Decree of 1953 had to be re-enacted. This step was taken by Decree No. 58-545 of June 24, $1958 .^{\text {st }}$ While in most respects it was merely a textual reproduction of the prior decree, it made some minor changes in the composition and procedure of the Commission Technique des Ententes and inserted some additions in the definitions of the offenses constituted by a "refusal to deal" or by discriminatory price increases. The former crime is now committed only by a failure to fill normal and bona fide orders within the limits of feasibility and under conditions conforming with commercial usages. The latter infraction now consists in the habitual resort to discriminaory sales terms or price increases not justified by corresponding augmentations in the costs of procusement of service. ${ }^{65}$

A decree of August 17, 1959, ${ }^{\text {eB }}$ introduced some further modifications in the composition of the Commission Technique des Ententes, ${ }^{67}$ eliminated some unnecessary formalities in the procedure, and, above all, provided for the publication of annual reports including the decisions of the Minister and the opinions of the Commission.

\section{III}

\section{THE RESULTING CURRENT PICTURJ}

\section{A. General Summary}

Froin the foregoing discussion of the legislative developments in France, it can be concluded that at least one line of her economic and juristic policies las taken the course of protecting workable and working

68 Syndicat des grossistes en matérial électrique de la région de Provence et autres, Conseil d'Etat June 18, 1958, [1958] Rec. Cons. d'Etat, 358 (1958), Juris-Classeur Périodique [hereinafter cited as Juris-Class. Pér.] No. 10727. As a result, convictions under the pertinent sections of the decree of 1953 had to be set aside, Lissac c. Daire, Cour d'Appel de Paris, (90 ch. corr.) Oct. 29, 1958, [1958] Juris-Class. Perr. No. 10864; De Lassus de Saint Genies, Trib. corr. Seine, (12e ch.) Oct. 28, 1958, [1958] Juris-Class. Pér. No. 10880.

8s Decree No. 58-545, [1958] Dall. Bull. Lég. 447. Its legality is discussed by Auby, Limitations apportées d lexercise, par le Gouvernement, de pousvoirs spkciausx: Apropos de la légalite du decret du 24 juin 1958 modifiant certaines dispositions de loodinnance no. 45-1483 dis 30 juirt 1945, [1960] D. I, 46.

65 The italicized words are the amendments.

66 Decree No. 59-1004, [1959] D. IV, 574.

${ }^{67}$ The commission is now composed of fourteen members. Its president is a Councillor of State, a justice of the Court of Cassation or a serior judge of the Court of Accounts; five members are selected from the members of the Council of State or the judiciary; six members are chosen by reason of their professional competency; and two members are elected because of their economic expertise. 
competition against restraints and impairments flowing from an untrammeled adherence to the principle of freedom of contract. Legislative enactments and decisional developments have combined in the suppression of certain agreements, whether of the horizontal or the vertical type, as restrictive, discriminatory, or abusive. On the other hand, it cannot be said that there exists a uniform and clear-cut policy against combinations in restraint of trade or monopolization. To be sure, cartels and similar combinations have been subjected to an ever increasing control and curbing of manifest abuses. But they still enjoy a wide area of toleration and legitimate action and, above that, there are many conditions or sectors of the economy in which the government considers combinations and their discipline as salutary and in the public interest with the attendant grant of privileges and subsidies. ${ }^{68}$ As a result, the situation is not free from paradoxes and dilemmas.

As a matter of positive law the main statutory sources for the suppression of restrictive, discriminatory, or abusive business practices are to be found in Article 419 of the Penal Code and Articles 37 and 59 bis, ter and quater of the Price Control Ordinance of 1945, as amended. Conversely, legislative bases for the fostering or aiding of combinations are widely dispersed and quite obscure.

\section{B. Currently Existing Prokibitions and Their Interrelation}

\section{Article 419 of the Penal Code and the Gerreral Principles of Law}

Article 419 of the Penal Code and the general principles of law based upon it, as well as upon the proclamation of the freedom of trade, still serve as the ultimate palliatives against unabashed and abusive restraints of competition and are invoked by the courts, with increased liberality, to vindicate the interests of consumers or obstinate competitors, or to relieve unwilling participants.

Thus, the Court of Cassation not long ago upheld a judgment by the Court of Appeals of Paris which condemned the blacklisting of a perfume store owner by the trade association of perfume manufacturers on account of violations of his resale price maintenance obligations and awarded damages to the boycotted plaintiff. ${ }^{69}$ Likewise, the courts have held invalid and

68 For a recent forceful advocacy of the necessity and advantages of cartels in manufacture or export trade by a government official charged with economic administration see Teissèdre, Les groupements d'exportateurs: Effort d'adaptation au Marché Commin, 1958 RevoE Do MARChé CoMnoron 404 (No. 8); for a more resigned appraisal see Mérigot, Les données économigues du problème do la législation des ententes en France, in Moreau et Mérigot, Les entertes professionnelles devant la loi, op. cit. supra note 10, at 7 .

69 Groupement des parfumeurs de marques réglementées c. Berthier, Cour de Cassation, (ch.civ.) May 9; 1957, [1957] D. II, 665, with note by Esmein, upholding Cour d'Appel de Paris, June 23, 1953, [1954] D. II, 366, with note by Léauté. 
unenforceable agreements by bakeries, prohibiting supplying of grocers and other retailers ${ }^{70}$ or home delivery services. ${ }^{71}$

However, the main sources of judicial or administrative action are now the detailed provisions codified in the Price Control Ordinance of 1945, as amended, especially in articles 37(1)-(5) and 59 bis and ter.

\section{Particular Restrictive Practices Prohibited by Ordinance No. 45-1483}

As has been discussed in the previous section in connection with the development of French law relative to the protection of competition, Ordinance No. 45-1483, as currently applicable, contains in article 37 a catalogue of specifically proscribed restrictive practices. ${ }^{72}$ This list has been lengthened and modified in details by a series of enactments passed since the original enactment in 1945, especially by Decree No. 53-705 for the preservation or re-establishment of free commercial and industrial competition and Decree No. 58-545, re-enacting it with shight modifications. The most important of these prohibitions are those against (a) discriminatory refusal to deal (article 37 (I) (a) first branch) ; ${ }^{73}$ (b) habitual discriminatory price increase (article 37 (I) (a) second branch) $;^{74}$ (c) discriminatory restriction of store hours with respect to particular commodities or services (article 37 (I) (b)) $;^{78}$ (d) tie-ins (article $37(\mathrm{I})(\mathrm{c})$ ) $;^{78}$ (e) fixing of miniunum resale prices (article $37(4)) .^{77}$

The list shows that French law contains no special provision against exclusive dealing (requirement) contracts as such, apart from the above-

70 Boulangers d'Aix-les-Bains c. Mallen et Guichet, Cour d'Appel de Chambéry, May 26, 1953, [1954] D. II, 365.

71 Vattement c. Amette, Cour d'Appel de Rouen, (2० ch.) Nov. 14, 1957, [1958] D. III, 138; Andouin et autres c. Fortin, Cour d'Appel de Poitiers, July 2, 1954, [1954] D. II, 771.

72 As explained before, the decree penalizes also other pricing practices which, without being restrictive, are deemed to be in violation of the public price controls. Thus, art. 36(9) penalizes sales or offer of sales at conditions constituting disguised additions to the quoted price, construed in Min. Public c. G., Trib. corr. Alès, Oct. 26, 1956, [1956] Juris-Class. Pér. No. 9593; art. 36(13), mentioned supra in the text at note 47 penalizes the coupling of sales and service contracts with the trading of other goods or services except for the satisfaction of personal or family needs. The latter interdiction supplements the general prohibition of tie-ins, made by art. 37 (I) (e), susprat note 43 .

73 See supra note 58.

74 See supra note 58.

75 See supra note 43.

${ }^{76}$ See supra note 44 . In addition to the proscription of express tying contracts, French law specifically prohibits and penalizes hidden tie-ins by means of stamps for or outright gifts of "free" merchandise to purchasers. A statute to the effect was passed in 1951, Law No. 51-356 of March 20, 1951, [1951] D. IV, 89, and supplemented by the Interpretative Governmental Decree No. 51-1178 of Sept. 19, 1951, [1951] D. TV, 366. The latter was invalidated in part by the Council of State in 1956, Société Approvisionnement Livraison, Vente et Publicité, C. E. June 1, 1956, Rec. Cons. d'Etat 216 (1956) [1957] Juris-Class. Pér. No. 9749, with note by Hémard. For a recent Court of Cassation decision applying the statute see Borocco et autres, Cour de Cassation (Ch. crim.) Nov. 12, 1957, [1958] D. II, 271, with note by Hémard.

77 See supra note 59. 
mentioned statute of $1943,{ }^{78}$ which restricts their duration to ten years. Accordingly, it has been held that an agreement whereby a retailer has obligated himself vis-à-vis a manufacturer to procure all his requirements of a particular class of merchandise from the latter is unaffected by the Decree of 1953 and enforceable. ${ }^{79}$ Conversely, the courts likewise have held that grants of exclusive territorial franchises for the sale of particular products, stipulated between a manufacturer and certain dealers, do not constitute an undue discriminatory refusal to sell withm the meaning of the Decree of 1953 and that they are enforceable, by quasi-delictual action, even against third parties disregarding such arrangement. ${ }^{80}$ Where, however, the producer or wholesaler has not established a system of exclusive distributorships his failure to supply customers without legitimate cause falls within the notion of a discriminatory refusal to sell, proscribed by the Decree of $1958 .{ }^{81}$ The interpretative circular of February 15, 1954, mentioned above, is in accord with these results. ${ }^{82}$

The aforementioned prohibition against the fixing of minimum resale prices or minimum mark-ups is very broad in its scope. It clearly applies to all types of vertical arrangements, whether by means of formal or informal, express or tacit, understandings or by means of price lists of schedules and regardless of whether they emanate from a single person or combination. ${ }^{83}$ The notion of minimum prices and mark-ups includes the cases where no variations are permitted. ${ }^{84}$ Exemptions may be granted by orders of the appropriate Mimisters. The decree lists as proper instances demands by producers of patented articles or products meeting special standards as to quality or dimensions.

78 See supra note 44.

79 Epoux Ruer c. Soc. des Grandes Brasseries de Charmes, Cour d'Appel de Colmar of Nov. 5, 1958, [1959] D. II, 183.

80 Soc. Guerlain c. Morand, Cour d'Appel d'Aix (2e ch.) Oct. 14, 1958, [1959] Juris-Class. Pér. No. 10924; Editions G. P. c. Brunel "Le Crayon d'Or," Cour d'Appel de Bordeaux (2० ch.), Dec. 10, 1958, [1958] Juris-Class. Pér. No. 10933; Soc. Guerlain c. Dame Vandanjou, Trib. Comm. Nantes April 23, 1956, [1956] Juris-Class. Pér. No. 9640; Soc. Guerlain c. Soc. Marie Antoinette Trib. Comm. Nice April 29, 1955, id. with note by Plaisant and Lassier.

81 Min. Pub. c. Bugnon, Trib. Corr. de Lyon, Oct. 3, 1956, No. 9790 [1957] Juris-Class. Pér with note by Plaisant and Lassier; Daire c. Lissac et Sté. Industrielle de Lunetterie, Trib. Corr. de la Seine $\left(12^{\circ} \mathrm{ch}\right.$.) Dec. 23, 195\%, [1958] Juris-Class. Pér. No. 10427, reversed because of invalidity of decree of 1953, Cour d'Appel de Paris ( $9^{\circ}$ ch.corr.), Oct. 29, 1958, [1958] Juris-Class. Pér. No. 10864.

82 Circular of February 15, 1954, Section I, A., [1954] D. IV, 96, at 97 (1954).

83 Circular of February 15, 1954, Section II, A. Plaisant and Lassier, Les ententes industrielles sous forme de sociétés ou d'associations, JuRIS-CrAsSEUR DES SocIÉTÉs, 178 at .9 (1955) suggest that art. 37(4) does not apply to resale price maintenance pursuant to a horizontal agreement. Even if this were correct, such agreements still would be prohibited by articles 59 bis and $37(3)$.

84 See the statements to that effect in section IIB of the Circular. 


\section{The General Prohibition Against Concerted Restraints of Trade}

It goes without saying that the most important portion of the French law for the protection of competition consists in the generalized prohibition of concerted practices in restraint of trade and the establishment of a special administrative machinery for the investigation of possible violations. ${ }^{85}$

Article 59 bis of Decree No. 45-1483, as inserted by the Decree of 1953, proscribes in general terms "all concerted actions, agreements, express or tacit understandings, or coalitions, in whatever form and for whatever reason, which have as their object or may have as their effect a restraint of the free exercise of competition, by hindering the lowering of the costs or prices or by favoring an artificial rise of the prices." While the scope of this prohibition is very broad, nevertheless it must not be overlooked that, as Circular No. 65 of March 31, 1954, ${ }^{88}$ emphasizes, its terms outlaw concerted restraints of the full exercise of competition only if they are susceptible of a deleterious effect on the price level. Actions of this type are, in particular, voluntary limitation of production or sales, sanctions against exceeding sales quotas fixed in advance, division of primary materials or orders among the cartel members, and division of customers according to geographical criteria. ${ }^{87}$

Moreover, the law provides for exemptions. The latter are based either on special legal authorizations or upon the ground that the measures in question have the effect of improving and extending the outlets for the production or of assuring the development of economic progress through rationalization and specialization. ${ }^{88}$

In order to facilitate the ascertainment and proper appraisal of the rather complex economic factors which determine the applicability of the law a special advisory administrative tribunal, called Cominission Technique des Ententes, is established. It is in charge of the formal investigations which are initiated either upon the request of the Mimister of Economic Affairs or upon the Commission's own motion. ${ }^{89}$ It holds hearings which, however, are not open to the public..$^{\infty 0}$ Its opimions which are advisory in nature must be based on stated findings and may contain recommendations concerning the practices under examination. ${ }^{.1}$ Originally the

85 Decree No. 53-704 of August 9, 1953, art. I.

86 Supra note 57.

87 Circular No. 65, at p. 10.

88 Decree No. 45-1483, art. 59 ter. as inserted by Decree No. 53-704.

89 Decree No. 54-97 of January 27, 1954, regulating the administration of the application of Decree No. 53-704, [1954] D. IV, 86, as amended by Decree No. 59-1004 of August 17, 1959, [1959] D. IV, 574; see supra notes 56, 66, 67 and Durand, op. cit. supra note 56.

${ }^{90}$ Decree No. 54-97 of Jan. 27, 1954, art. 12, [1954]. IV, 86.

91 Id. art. 15. 
opinions of the Commission and the decisions of the Minister were considered confidential and not published. Decree No. 59-1004 of August 17, 1959,92 however, provided for the publication of comprehensive annual reports by the Commission, including, by way of appendix, the individual ministerial decisions and the opinions of the Commission. The Decree specified that this mandate included the period of operation prior to its enactment. A'ccordingly, the Commission has now published three reports covering the period of the years $1954-1957 . .^{83}$ In addition, the Minister of Economic Affairs gave a detailed summary of the experience during the first three years in reply to a parliamentary inquiry addressed to him in January $1957 . .^{\text {ss }}$

According to the information inparted by these sources the Commission, during the period froin April 9, 1954 to January 31, 1958, niade a final disposition in fourteen cases referred to it, of which thirteen terminated in formal opinions. ${ }^{9 x}$ In a number of these proceedings the Minister of Economic Affairs, acting upon the advice of the Conumission, proposed to the parties the measures deemed necessary to re-establish a sufficient degree of competition. So far as it can be deduced from the reports every instance where apposite his suggestions were accepted and carried out. As a result, all proceedings reported for the indicated period had terminated amicably. ${ }^{98}$

In the course of these thirteen interventions, the Commission and the Minister had the opportunity to crystallize the principles guiding the application of the law, that is, principles for the determination of whether a concerted action of the defined "anti-coinpetitive" character has been engaged in, and whether such conduct is exempt from the prohibition in view of the overall beneficial effects. ${ }^{97}$ In developing the criteria for the solution of the latter issue the Commission developed the approach of preparing "a veritable economic balance sheet." Practices without ulti-

92 Supra note 66.

93 J.O., Documents Administratifs, Nos. 1, 2 and 11 (1960). The first two reports are discussed by Plaisant and Lassier, Les trois premières années d'une politique des ententes, [1960] D. I, 61.

os Assemblée Nationale, 1957, No. 4987, J.O., Oct. 19, 1957, at 4569.

88 Rapport de la Conmission Technique des Ententes pour les années 1954 et 1956, J.O., Documents Administratifs No. I (1960); Rapport de la Commission Technique des Ententes pour l'année 1956, J.O., Documents Administratifs No. 2 (1960); Rapport de la Commission Technique des Ententes pour l'année 1957, J.O., Documents Administratif́s No. 11 (1960).

08 See Section III in the reply of the Minister of Economics to the parliamentary inquiry of 1957 , supra note 94, and the two reports of the Commission, supra note 95 .

97 See the comments to that effect in the reply of the Minister of Economic Affairs to the parliamentary inquiry of 1957 , suspra note 94 , and the discussion by the Commission in the three reports supra note 95 . See also the discussion of this new body of decisional law by Durand, op. cit. supra note 56, and Plaisant and Lassier, op. cit. suspra note 93.

98 See Section V, B in the reply of the Minister, supra note 96. 
mate advantages for the national economy and the consumers are condemned, ${ }^{99}$ while restrictive practices which, under existing conditions, tend to result in improvement of the market structure or technological progress are condoned, at least for the near future.

As the Minister and the Commission in its annual reports underscored, the criteria established by the Commission are essentially constructive. The Commission has endeavored not to tend toward a systematic suppression of cartels, but to obtain the approbation of the interested parties for its formulae of technical progress and general interest. For that reason it has favored agreements for concentration and specialization, at least as long as no danger of monopoly results.

Under the provisions of the Decree No. 45-1483, as amended, the courts possess jurisdiction to pass on the validity or invalidity of restrictive arrangements independent of the Commission and the courts are under no duty to refer such question to the administrative tribunal. Nevertheless the courts may seek or take cognizance of the opinion of the Commission without, however, being bound by its conclusions. ${ }^{100}$

${ }^{90}$ The response lists four types of effects which have led to the condemnation of the respective restrictive practices: (a) alignment of a common sales price on the basis of the highest costs in the branch; (b) crystallization of industrial or commercial positions which hamper the chances of the best placed enterprises for further advance; (c) creation of a factual monopoly for the benefit of a single distributor which renders the customers closely dependent upon a single merchant and does not permit them to discuss usefully either the price or the quality of service; (d) establishment of lists of minimum prices or discriminatory pricing practices.

100 See the discussion to that effect in Rapport de la Commission Technique des Ententes pour l'année 1957, J.0., Documents Administratifs No. 11, at 212 (1960). 


\section{APPENDIX}

STATUTORY PROVISTONS FOR THE PROTECTION OF COMPETITION IN THE ORDINANCE OP JUNE 30, 1945 RELATIVE TO PRICES, IN ITS CURRENTLY APPLICABLE FORM

ORDINANCE NO. 45-1483 OF JUNE 30, 1945 (AS AMENDED)

BOOK II

Article 37

VIOLATIONS AND SANCTIONS

Assimilated to the practice of illegal pricing is the act:

1. committed by any producer, merchant, manufacturer or artisan

(a) of refusing to satisfy, within the limit of his supplies and under conditions conforming to commercial usages, the demands of buyers of goods or for the rendition of services, provided that such demands do not present an abnormal character, that they come from bona fide demandants and that the sale of the goods or the rendition of the services is not prohibited by statute or regulation of the public authorities, as well as of habitually practicing discriminatory sales terms or discriminatory price increases which are not justified by corresponding augmentations in his net costs for the delivery or the service;

(b) in the absence of a special regulation applicable thereto, of restricting the sale of certain commodities or the rendition of certain services to certain hours of the day, although the enterprises or stores concerned may remain open for the sale of other goods or the rendition of other services;

(c) in the absence of a special regulation applicable thereto, of conditioning the sale of a product or the rendition of a service either upon the purchase of other products or of a required quantity or upon the rendition of another service;

(d) of not presenting, upon the first request by the officers indicated in Article 6 of the Ordinance of June 30,1945, relative to the ascertainment, the prosecution and suppression of infractions of the economic legislation, the statements, whether in original or copy, the delivery and preservation of which are provided for in section II of book III of the present ordinance;

(e) of taking, or attempting to take, in action, whether individually or in concert or coalition, with the view to defeating price regulation by threats of discontinuing his commercial, industrial or artisanal activity or by effective discontinuance of such activity;

(f) of practicing the withholding of stocks as defined below in article 45 of book III of the present ordinance; 
2. committed by any person, of withholding any stock of products contrary to the provisions of section I of book III of the present ordinance;

3. committed by any person responsible for a concerted action, of engaging, or incitting to engage, in a practice prohibited by article 59 bis of the present ordinance; 4. committed by any person, of conferring, maintaining or imposing a minimun limit upon the prices of products or for the rendition of services or upon commercial mark-ups, whether by means of tariffs or price lists or pursuant to understandings of whatever nature or form;

Subsection 4, above, does not apply to the cases where the products or services are the object of a dispensation granted by jomt order of the Minister for Economic Affairs, of the Minister of Commerce and the Ministers having an interest in the subject. This dispensation which in any event nnust be limited as to time may be accorded especially as a result of the novelty of the product or service, of the exclusiveness flowing from a patent, a franchise for exploitation or the deposit of a utility model, or of the exigencies of a list of charges, involving guaranty of quality and specification of condition, or of a publicity compaign for launching the same;

The enterprises, the beneficiaries or managers of which have been parties to a concerted action, agreenent, express or tacit understanding or coalition and have been convicted in application of the present decree, are barred from particjpation in all dealings with the state, public entities, public enterprises or enterprises in which the state or public entities own the majority interest, as long as they are not relieved of this disability by joint action of the Minister for Economic Affairs, the Minister of Commerce and the Ministers having an interest in the subject.

5. committed by any seller who effectuates retail sales on the instalinent plan or on credit, in whatever form, of not delivering to the purchaser to whom the credit is extended, a certificate of the clauses of the transaction, conpleted in the form determined by joint regulation of the Minister for Economic Affairs, and the Minister of Commerce and Industry;

The duphicate of this certificate signed by the purchaser must be preserved by the seller in the manner provided for in Article 48 of the Ordinance No. 45-1483 of June 30, 1958, relative to prices;

The foregoing provisions apply also to sellers who effectuate their sales by interposition of the enterprises and persons subject to the declaration of activity governed by article 5, last paragraph of the Law of June 14, 1941, relative to the regulation and organization of the professions connected with the profession of banking. 


\author{
BOOX III \\ PROVISION ANNEXED TO PRICE REGULATION \\ SECTION IV
}

Maintenance of Free Competition

\title{
Article 59 bis
}

All concerted actions, agreements, express or implied, understandings, or coalitions under whatever form or for whatever reason, which have as their object or may have as their effect the restriction of the full exercise of competition by placing an obstacle in the way of a lowering of production costs or sales prices or by favoring an artificial increase of the prices, are prohibited, except as provided in article 59 ter.

Every undertaking or agreement relating to a practice thus prohibited is void as a matter of law.

This nullity may be asserted by the parties or third persons; it cannot be interposed by the parties vis-à-vis third persons. It is determined ultimately by the ordinary courts of justice, to whoin the advisory opinion of the Commission, if one las been rendered, must be communicated.

Article 59 ter

The provisions of article 59 bis do not refer to the concerted actions, agreements or understandings:

(1) Which result from the application of the text of a statute or regulation;

(2) Which the origmators are able to justify as having the effect of improving or extending the outlets of the production, or of assuring the development of economic progress by way of rationalization or specialization.

\section{Article 59 quater}

There is established a Technical Commission For Restrictive Accords (Commission Technique des Ententes).

The Technical Commission for Restrictive Accords has the task of investigating forthcoming violations of article 59 bis as well as justification which may be produced by virtue of article 59 ter. Its decisions and opimons are rendered upon majority vote. In case of an equal split the vote of the president is decisive.

The officers im charge of the report to the Commission are designated jointly by the Minister for Economic Affairs and the Minister of Commerce. Their reports are communicated to the interested parties who are given the opportunity of presenting their observations to the reporting officers. They possess the investigatory powers provided for by book II of Ordinance No. 45-1484 of June 30, 1945. The reporting officers have advisory vote in the matters on which they report.

The secretariat of the Commission is supplied by the Minister for Economic Affairs. A representative of the Minister for Economic Affairs (Ofice of Price Administration) presents, in each matter, the observations of the ininistries interested therein.

After having obtamed the opinion of the Technical Commission for Restrictive Accord or if the Commission has not issued an opinion within six months from the date when it has acquired jurisdiction of the matter, or in cases of urgency, repeated offense or flagrant violations, the Minister for Economic Affairs may transmit the file to the district attorney, either with the view of applying Ordinance No. 45-1484 of June 30, 1945 , relative to the ascertamment, prosecution and repression of infractions of the economic legislation, or with the view of applying Article 419 of the Penal Code. 